Agaba is running berserk in the street, wielding a machete and prancing as if possessed. As he rants and raves, he seems oblivious of every one following him trying to stop him, to hear what the cause of his aggravations is. "I am going to kill someone today, in fact more than one! As many as will tell me that I do not come from this place! What does it take to come from this desert town after I have lived here for 30 years, and had twelve children here? If it is a football team they want I have produced it! So, what is it? I will truly kill someone!"

When he finally comes to a stop he looks very weary, frustrated and defeated. As if it would help to talk, he narrates his problems. He has lived in Kano for 30 years, paid all his tax here and had all his 12 children in this town. Three of the children have gained admission to the university and the State would not give them scholarship. "Do you know why? They are telling them that they do not come from Kano! Where do they come from, every one?" That is why I am going mad, and I am right to do so, do you hear!?" He calms down again, and in a very subdued voice asks, "Where do these children come from?" ii

\title{
Introduction
}

In this article, we examine the question of citizenship and the different ways in which this may determine rights and privileges in Nigeria. The simple, yet complex way in which this can be thrown into sharp relief is to ask the question, Who is a Nigerian citizen? How is this determined and defined by: a) law, b) other factors? Even when citizenship is defined by law or wrested by individuals/groups, it is important to interrogate how Nigerians perceive their own citizenship. Some of the factors to look at include location/space, ethnicity, gender and religion. On the basis of who they think they are and the ways in which they have interpreted their own belonging in the country, people outline what they expect their entitlements to be. How have these expectations been shaped, and do they change over time and space?

The reality of the Nigerian situation is that although citizenship is constitutionally determined by both ancestry and by place of birth or sojourn (The Nigerian Constitution of 1999: p A888), in practice Nigerians always revert to and insist on ancestry as the true and recognizable determinant of who you are and what you may be entitled to. What is in practice therefore in every day official and public spheres is in conflict with the provisions of law. This is playing itself out in the life of Agaba and other Nigerians in similar circumstances. The issues at stake are about how Agaba's and any other Nigerian's state of origin/ancestral home limits his entitlements and how that limitation transfers to his offsprings, even when such children no longer have any serious knowledge of or interaction with the State they come from constitutionally.

How did the practices and perceptions of exclusion and non-citizenship expressed by Agaba, come about? The question of citizenship, the issues of entitlement and the way in which Nigeria has been governed and its natural wealth managed, have all been under constant scrutiny since independence in 1960. Indeed, some of these issues have resulted in a dvil war in the country and ushered the military into 
Nigeria's political scene for over 20 years. Some of the vexed issues that beg answers today are traceable to the way in which Nigeria came into being. What is known as Nigeria today is a patchwork knitted together by a history of colonisation. There are three major ethnic groups and correspondingly, three power blocks in the country. These are Hausa/Hausa-Fulani, Yoruba and the Igbo (the 'Wazobia' groups). It is the unification/merger of these different nationalities, plus a myriad of others, into one country that has remained both a point of interest and area of aggravation for the political practice in Nigeria.

In the first republic from 1960 to 1966, the discussion of these incongruities were incoherent and poorly mediated, thereby resulting in a war; in the military era Nigerians were silenced by the gun. Therefore in this current democratic period, there is another opportunity to discuss the issues again. Indeed, the discussions have been going on already, either violently or 'peacefully' in legislative houses.

\section{Identity and citizenship}

What is citizenship, and how does it interact with how people construct their sense of identity? Isin and Wood argue that citizenship has been conceived as a status (legal, juridical) while identity is a socially-defined, relational concept that classifies and positions individuals (1999:19). They also go on to argue that while citizenship and identity are not the same, they are not antinomic either: "There is a tension between the universal aspirations of citizenship and the particularlist claims of identity. Nevertheless, since citizenship has never been universal, it is more appropriate to interpret different formation of group identities as claims for recognition of citizenship rights' (ibid: 20). Perhaps Lister's (1997:197) call to reconstruct citizenship along pluralist lines, would be a useful step towards accommodating or understanding the kind of tensions between group identities and citizenship rights that are at play in Nigeria today.

However, competing identities in Nigeria's multi-ethnic society make such a proposal for inclusive citizenship difficult to achieve. In a tally that exceeds 370 ethnic groups, the Hausa, Fulani, Ibo and Yoruba predominate (Otite 1990). But while the others are lumped together as minorities, the sizes vary from a few hundred thousand to 2-3 million. In both North and South, it is possible to identify tiers of minorities, where the first tier refers to the centre and its politics, while the second pertains to the state and local council levels. This tiered nature of majority and minority ethnic groups means that some of the national minorities are de facto majorities at the other levels. Furthermore, similar fears of domination, and denial of self-determination at the centre, are played out at these other levels. Hence, the construction of a pan-Nigerian identity based on equality of citizens and a common political practice remains elusive. Political mobilisation, even by political parties, tends to remain within the realm of sectarian loyalties.

The centrality of the power of the state and its layer of ruling classes have played a major role in strengthening such ethno-political identities. Military dictatorships centralised political power, and distributed resources in a command-style top-down 
fashion. Recipients of benefits thus had to be in line with the government of the day, or in other words, 'the ethnicity of the president' (Mamdani, 1996:289). This implies that control of the central government is not only necessary but also expedient. The party at the centre will be well placed to effect changes and benefits to its followers especially when it is regionally and ethnically determined. This prevalence of sectarian over citizenship rights can be traced back to misguided decisions made by colonial authorities.

\section{The colonial construction of citizenship}

What is now known as Nigeria was in fact a deliberate colonial creation, which arose from merging the Protectorates of Northern and Southern Nigeria into the Colony of Nigeria in 1914 (Ihonvbere and Shaw, 1998). A combination of the activities of the Royal Niger Company and later British colonial rule, wiped out or distorted existing cultural and political patterns. Prior to 1914, Nigeria was organised into protectorates, then colonies. In 1906, the colony of Lagos was merged with the protectorate of the Niger Coast to form the colony and protectorate of Southern Nigeria. This, together with the protectorate of Northern Nigeria, made up the Nigerian entity. Each of the protectorates "was a sprawling territory of separate ethnolinguistic groups, each with its own distinctive history, language, social custom, and beliefs. Nigeria is therefore a veritable mosaic of nationalities; it has within its borders several hundred ethnic groups with distinct languages and cultures" (Okehie-Offa, 1996:1).

After the amalgamation, the colonial authorities proceeded to divide the country in such a way as to lay the foundation for the current structural and citizenship impasse. In 1939, the Southern provinces of the country were split in two, but the North was left intact. The North alone in size occupies about $74 \%$ of the entire landmass of the country and according to (contested) population counts, is home to more than half of the population. This lopsided division has consequences for the way elections are conducted and who occupies the central administration. "Since the electoral system adopted in the country was based on the principles of proportional representation and majority rule, Northern Nigeria had a competitive advantage over the Southern regions in Federal politics" (Okeke, 1992:18), giving the North domination in political and territorial terms over the divided Southern regions.

Resistance to colonial authority was dealt with through co-optation or repression. The British transformed sections of local African elites into the principal colonised employees of colonial service. Sections that resisted were excluded or exterminated. In the context of colonial indirect rule, the 'native rulers' were symbols of the colonial state, with concomitant executive, legislative and judiciary powers. Where these leaders were recruited from inside the ethnic group, peasant resistance took class form against oppression and tyranny. Where they were recruited from outside the group, resistance assumed an ethnic or ethno-religious character:

'The form of rule shaped the form of revolt against it. Indirect rule at once reinforced ethnically bound institutions of control from within. Ethnicity 
(tribalism) thus came to be simultaneously the form of colonial control over natives and the form of revolt against it. It defined the parameters of both the Native Authority in charge of the local apparatus and of resistance to it' (Mamdani, 1996:23).

This is, to some extent, the genesis of the ethnic strife in Nigeria today. Further, the legacy of colonial 'divide and rule' has been compounded by subsequent decades of military rule which, unaccountable and repressive in nature, undermined democratic values and skewed political space. Military intervention in Nigeria especially that which ousted civilian regimes, has been of the 'veto type' (Nnoli, 1983), which retraditionalises or retribalises political activities by restricting or even banishing popular participation, thus shifting allegiance from superordinate (macro) to subordinate (micro) units, from state to nation, from nation to ethnic groups, and from ethnic groups to the extended family (Oyovbaire, 1985).

Resistance to exclusion from decision-making during the colonial period took the form of a nationalist movement for independence and citizenship. By the mid-1940s, an anti-colonial nationalist movement had galvanised most of the radical elite and militant workers' organisations in the struggle. The British response was to ban these organisations or imprison their leaders, and to depict the struggle as a Southern Nigeria phenomenon, keeping the north at bay. However by 1950, an anti-colonialist nationalist party (NEPU) emerged in the north which began to win support away from the British. Repression was unleashed on NEPU, and members were arrested, deported or jailed. Such efforts of the anti-colonialist radical nationalists were moves towards establishing a future democratic society with an inclusive citizenship.

Nationalist citizen mobilisation took place again in the 1980s, in resistance to the introduction of structural adjustment policies. This time, not only workers and students but citizens from broad strata of society were involved. The fast-growing military regime however, ignored protests and went ahead with the policies that exacerbated poverty, and drove people back to ethno-religious and communal struggles over resources. However, the colonial and the 1980s experience of citizen mobilisation are important historical expressions of citizenship as resistance to exclusion.

\section{Citizenship and exclusion in contemporary Nigeria}

As explained above, what is today Nigeria was cobbled together by fiat, when the Northern and Southern Protectorates were merged in 1914. The nature of citizenship has remained controversial ever since, and is a constant national project that cannot be taken for granted. We here refer to citizenship as the legal rights of people who, by descent or naturalisation, have rights, privileges and obligations with reference to a nation, irrespective of sex, religion, ethnic or other affiliation. Inclusive citizenship refers to the extent to which all people can claim rights and whether the rights claimed are equal for all people (DFID, 2000:7). The 1999 Constitution of Nigeria (Chapter II, Section 17,2 ) states that: 'every citizen shall have equality of rights, obligations and opportunities before the law'. However, despite such constitutional provisions and 
those of international agreements such as CEDAW ${ }^{\mathrm{iii}}$, the concept of inclusive citizenship in Nigeria appears to be a mirage. While theoretically, citizens as defined by the constitution, are granted the right to equal treatment, political participation and benefits in every day life, the practice has always been different. The discrimination, marginalisation, power domination, class divisions and exclusion that characterise Nigeria's political processes, though lacking constitutional backing, continue to wax stronger.

Why does this happen? Earlier in this article, we mapped the ethnic landscape that is Nigeria. It will be useful to now look at the ways in which this landscape plays out in everyday Nigerian life. In Nigeria, as in most developing countries, the centres of development are located in the urban centres which serve in most cases as the administrative and commercial as well as industrial capitals and headquarters. Most of these urban areas are located in the ethnic majority enclaves of Kaduna, Kano or Enugu and Onitsha or Lagos and Ibadan. Since job opportunities are only located in these urban centres, the location of which reflects the dominance in the power equation of the ethnic majorities in the politics of the country, the minorities became migrant labourers to these urban centres. Here, severed from their relatives back home, discriminated against by the host ethnic group who at every opportunity draw attention to their status as "foreigners" trying to take the food away from the "sons of the soil", the migrants have no option but to reach out to their kinship ties to dispel their insecurity.

Perhaps the greatest threat to citizenship in Nigeria lies in the concept of foreigner. In Nigeria, whether you were born in a state or had lived and worked there all your life, as long as it is not your state of origin, you are still a stranger, a non-indigene who is not entitled to the status and benefits enjoyed by those who are "bona fide" owners of the state. Even when you have a job with the state, such a job is on a contract basis. The 'northernisation' policy defined in 1957 by the Public Service Commission of the Northern Region as a hiring system, illustrates this phenomenon vividly: "If a qualified northerner is available, he is given priority in recruitment; if no northerner is available, an expatriate may be recruited or a non-northerner on contract terms" (quoted in Nnoli, 1978:191). It is only if the establishment is a Federal one that tenure appointment can be awarded but even then, the tendency nowadays is that the states insist that certain positions within the Federal establishments in their states be reserved exclusively for their people, even if there are better qualified Nigerians from other states desperate for the job. It is no wonder therefore that ethnic identity articulation becomes a matter of necessity in the cities and one that drives a very strong wedge between being a Nigerian and being a member of an ethnic group.

Realising a more inclusive citizenship is further complicated by the manipulations of identity over Nigeria's changing social and political space. The issue of changing space and identity came to the fore after the series of state creation exercises during the military regimes. After each exercise, the definition of indigeneity changed such that some of those who had been fellow citizens effectively became excluded. For example, when Nasarawa State was carved out of Plateau State, the indigenes of the 
new state were requested to leave within a short space of time. All of a sudden, the people who had been bona fide citizens of Plateau State were now strangers and no longer welcome in their offices. The ensuing acrimony over asset sharing continues today. These changing criteria for inclusion and identity further complicate the challenge of national unity. While Nigerians are encouraged to 'rally round the flag', the reality indicates that just who Nigerians are is uncertain. People who belong in one situation are regarded as foreigners in another.

In effect, which of several identities becomes paramount depends on the issues, the relative power between the key contestants, and who among the contenders stands to win or lose. In contention, some valued resource is always at stake, such as opportunities for education, employment, or representation in decision making, and the struggle is to exclude others. The issue is who is doing the labelling and excluding of 'others', and who has the power to enforce such labels. The group on the receiving end on the other hand, is often able to overcome whatever differences they had, and act in unison. In this sense, the assailed group accepts the labels and uses these as a rallying point. This explains why ethnicity sometimes takes precedence over religion, and vice versa.

Alternatively, finding themselves excluded on the grounds of identity, disenfranchised groups may choose an 'exit' option. This refers to a disengagement or retreat from the state by disaffected or marginalised segments of the citizenry and in the same vein, the creation of parallel social, cultural, economic and political systems that compete with state structures (Osaghae 1998). The reciprocal rights normally associated with state-citizen relations are absent. In the Nigerian case, various forms of exit are apparent, especially the creation of parallel and selfgoverning economic structures and socio-cultural and juridical activities. As a result of the failure of the state to provide security for the lives and properties of its citizens, the 1990s witnessed an upsurge in the creation of vigilante groups such as the 'Bakassi Boys' in eastern parts of the country. This group engages in security duties with the open support of the state as does the O'odua Peoples Congress which, despite its overt political programme, engages in police duties by meting out instant justice to suspected criminals. Thus the inability of the state to provide public goods and services, combined with the authoritarian style of military dictatorships, has further alienated the citizenry and made them turn to alternative sources of support such as fundamentalist religious movements, ethnic self-help unions, black market networks, secret cults or outright exile.

But in addition to all these, there is the major factor of resource control and management. Perhaps the crisis and eruptions which jump to the fore all the time are fuelled by the fact that the places and peoples where resources such as oil originate, are separated from the usage and benefits of these resources in other locations. Oil accounts for 85 percent of Nigeria's export earnings. It is therefore correct to say that this is the main resource and lifeline of the nation. However, the benefits accruing to the places where oil comes from are far less than those enjoyed by the ethnicities which control state power. 
Has all this changed with the Third Republic, and the return to civilian rule? Recent research suggests that Nigerian people's perceptions of their rights as citizens are limited and negative. In discussions with men and women in Kaduna and Benue States, TFDC researchers noted that: 'people always wrote themselves out by saying "Us! We don't count! It is government and the politicians that matter". Overall, the situation amounts to a sense of non-citizen on the part of the ordinary Nigerians. It is also a defeat of human agency when one witnesses the disarticulated manner their sense of being operates in a divide of "us" and "them"' (Abah, 2001).

\section{Methodologies for change}

We have seen how citizenship in Nigeria is constructed around identities that are exclusionary and competing, the legacy of the historical colonial construction of the Nigerian nation which created a power imbalance between the northern and Southern States. Furthermore, access to resources continues to depend on ethnic allegiances and ethno-political systems of patronage. In this context, how can people begin to perceive citizenship in more inclusive and participatory terms? The work of civil society groups such as Theatre For Development Centre (TFDC) begins to address this need. Through participatory research into the nature of the problems and the factors which determine citizenship in Nigeria, TFDC is exploring how people perceive their citizenship and how such perceptions influence and affect what they consider as their rights. Participants in the research put their knowledge in a 'basket' for community members to learn from, access and deploy. Some of the approaches include Citizen Drama (an excerpt from which introduces this article), in which an itinerant person whose citizenship status is constantly in flux, is in search of belonging. In structuring the citizen drama, a storyteller should bring wisdom from the people into the performance. He may be the narrator as well as the citizen in search of a nation. He may be collapsing the past into the present, and without doubt, these age-old practices contain their philosophy of life. The combination of these strategies are raising critical questions such as: Are these philosophies challenged by the new development in the country? Are they no longer relevant, or has there been a case of refusing to acknowledge their applicability in the new situation?

The research is about exploring new spaces for citizenship action that encourage mobilisation without fear of reprisal, and a new inclusive culture that respects people's understanding and practices of citizenship, rights and positive ways of deploying them to good effect. Today, the issue of exclusion is an urgent one for many Nigerian ditizens. If we recall Agaba's last question "Where do these children come from?", it demands an answer, not only from the State but from every Nigerian. Every Nigerian should examine the issue of exclusion, so that when the question is answered it is not Agaba alone that will find satisfaction; it is not him alone who may need to plan follow-up action. The answer to the questions raised by the drama cannot be answered within the drama. They lie outside the fiction of the drama, in people's real lives and actions. 
Theatre provides space to test approaches and suggested options for dealing with these issues. In practice this works by intervention and interrogation; what Boal has called forum. The audience provides answers and suggested actions, which are incorporated into the action so that the analysis happens from within; so that suggested actions are tried out and the limitations of such suggested actions are discovered. The drama as it were will be re-written, expanded and perhaps dissolved in performance. The bystanders, the spectators who have switched from watching to doing the drama are the subjects and victims of the problem that Agaba has catapulted into the public domain.

\section{Bibliography}

Bamishaye, A. (1976) "Ethnic Politics as An Instrument of Unequal Socio- Economic Development In Nigeria's First Republic", in A.O. Sanda (ed), Ethnic Relations in Nigeria, The Caxton Press: Ibadan.

Ihonvbere, J. and Shaw, T. (1998), Illusions of Power: Nigeria in Transition, African World Press, Asmara.

Isin, E. \& Wood, P. (1999), Citizenship and Identity, Sage Publications: London, Thousand Oaks, New Delhi.

Lister, R. (1997) 'Citizenship: Towards a feminist synthesis', Feminist Review, No.57, pp. 28-48.

Mamdani, M. (1996), Citizens and Subjects: Contemporary Africa and the legacy of late colonialism, Princeton University Press: Princeton.

Nnoli, O. (1978) Ethnic Politics in Nigeria, Fourth Dimension:Enugu

Nnoli, O. (1995) Ethnicity and Development in Nigeria, Avebury, Aldershot, England.

Okehie-Offoha, M.U. (1996) Introduction, in M.U. Okehie-Offoha and M.N.O. Sadiku (eds), Ethnic \& Cultural Diversity in Nigeria, Africa World Press: Trenton, New Jersey.

Okeke, O (1992), Hausa-Fulani Hegemony: The Dominace of the Muslim North in Contemporary Nigerian Politics, Acena Publishers: Enugu.

Otite, O. (1990) Ethnic Pluralism and Ethnicity in Nigeria, Shaneson: Ibadan

Oyovbaire, S. (1985), Federalism in Nigeria, London: Macmillan Publishers.

DFID, 2000:7).

The 1999 Constitution of Nigeria (Chapter II, Section 17, 2).

\footnotetext{
${ }^{i}$ The authors would like to thank John Ayam, Ladi Deborah Alabi, Toure Kazah-toure, Ogoh Alubo, Paul Muftwang and Samuel Egwu for their contributions to this article.

ii Extract from a Theatre for Development Centre (TFDC) citizen drama, cited in Oga, Steve Abah: 'Of Drama and Voices in Encountering Citizenship, Participation and Accountability', Ahmadu Bello University, Nigeria, June 2001.

iii The International Convention on the Elimination of all Forms of Discrimination Against Women, signed and ratified by the Government of Nigeria.
} 